\title{
GENEZA, POJĘCIE I FUNKCJE KRAJOWEGO SYSTEMU ZIELONYCH INWESTYCJI
}

\section{GENESIS, CONCEPT AND FUNCTIONS OF NATIONAL GREEN INVESTMENT SCHEME}

\section{STRESZCZENIE W JĘZYKU POLSKIM}

System zielonych inwestycji stanowi pochodną mechanizmu przewidzianego w art. 17 Protokołu z Kioto ${ }^{1}$, który polega na wykorzystaniu środków pochodzących ze sprzedaży jednostek przyznanej emisji $\left(\mathrm{AAU}^{2}\right)$ na realizację działań związanych z ograniczaniem negatywnych zmian klimatu i ograniczaniem emisji gazów cieplarnianych. Zainteresowanie wprowadzeniem systemu zielonych inwestycji pojawiło się wśród państw europejskich, które na przełomie lat 80. i 90. $\mathrm{XX}$ wieku przechodziły transformację ustrojową i społeczno-gospodarczą w związku z czym posiadają teraz nadwyżkę jednostek przyznanej

* Magister prawa, doktorantka KPOŚ WPiA UMK w Toruniu.

1 Dz. U. z 2005 r. Nr 203, poz. 1684.

2 Ang. Assigned Amount Unit. 
emisji. Do krajów tych zalicza się Polskę, Rosję, Litwę, Łotwę, Estonię, Ukrainę, Czechy, Słowację, Rumunię oraz Bułgarię. Jednostki przyznanej emisji mogą zostać sprzedane krajom z Załącznika I do Protokołu z Kioto, które nie są w stanie sprostać celom redukcyjnym. Z uwagi na to, iż brak jest międzynarodowej regulacji traktatowej, która jasno określałaby ramy systemu zielonych inwestycji, krajowe regulacje prawne państw wprowadzających ten mechanizm mogą się od siebie różnić. W prawie polskim system zielonych inwestycji został utworzony na podstawie art. 22 ustawy z dnia 17 lipca 2009 r. o systemie zarządzania emisjami gazów cieplarnianych i innych substancji ${ }^{3}$.

\section{Słowa kluczowe w języku polskim}

System, zielone inwestycje, handel, emisje.

\section{STRESZCZENIE W JĘZYKU ANGIELSKIM}

Green Investment Scheme (GIS) derives from a mechanism specified in Article 17 of the Kyoto Protocol which consists in using funds from selling the assigned amount units (AAU) for actions related to limitation of negative climate changes and greenhouse gases emission. European countries in which the political and the socioeconomic transformation had occurred at the turn of the 80's and 90's of $20^{\text {th }}$ century and now have AAU surplus are interested in implementing GIS. These countries are Poland, Russia, Lithuania, Latvia, Estonia, Ukraine, Czech Republic, Slovakia, Romania and Bulgaria. AAU's can be sold to Annex-I countries of the Kyoto Protocol that are not able to comply their reduction targets. Because of lack of international treaty regulation clearly regulating a framework of GIS, each country national regulations implementing GIS can be different. In Polish law GIS was established by the article 22 of the Act on the system for managing the emissions of greenhouse gases and other substances of July 17, 2009.

\section{Słowa kluczowe w języku angielskim}

Scheme, green investment, emission, trading.

System zielonych inwestycji (Green Investment Scheme GIS) stanowi mechanizm o międzynarodowym rodowodzie, któ-

\footnotetext{
3 Dz. U. z 2009 r. Nr 130, poz. 1070 ze zm.; dalej cyt.: ustawa z 2009 r.
} 
ry zaczyna odgrywać istotną rolę $\mathrm{w}$ prawie międzynarodowym publicznym jak również prawie krajowym państw, w których jest normowany. Mimo swego znaczenia do tej pory nie został on usankcjonowany $\mathrm{w}$ prawie międzynarodowym publicznym i w tym obszarze stanowi pojęcie pozanormatywne, a tymczasem zaczyna stawać się pojęciem normatywnym w krajowych porządkach prawnych.

Zainteresowanie systemem zielonych inwestycji pojawiło się wśród państw europejskich, które na przełomie lat 80. i 90. XX wieku przechodziły transformację ustrojową oraz społeczno-gospodarczą, do których zalicza się Polskę, Rosję, Litwę, Łotwę, Estonię, Ukrainę, Czechy, Słowację, Rumunię oraz Bułgarię. Mimo, iż wymienione państwa znajdują się na różnym etapie regulowania funkcjonowania systemu zielonych inwestycji w ich porządkach prawnych, wszystkie one zmierzają do stworzenia przejrzystego systemu służącego zarówno ochronie środowiska jak i rozwojowi społeczno-gospodarczemu ${ }^{4}$.

System zielonych inwestycji pojawił się w prawie polskim w art. 22 ustawy z dnia 17 lipca 2009 r. o systemie zarządzania emisjami gazów cieplarnianych i innych substancji. Jak dotąd powstało niewiele polskich opracowań dotyczących tego mechanizmu, co być może spowodowane niedługim doświadczeniem $\mathrm{z}$ jego funkcjonowania w polskim porządku prawnym. Niniejsze opracowanie ma na celu przybliżenie przyczyny wyodrębnienia się omawianego mechanizmu, określenie jego pojęcia oraz nakreślenie funkcji, które spełnia.

Podczas II Szczytu Ziemi, mającego miejsce w Rio de Janeiro, przyjęto Ramową Konwencję Narodów Zjednoczonych w sprawie zmian klimatu, zwaną Konwencją Klimatyczną, sporządzoną w Nowym Jorku dnia 9 maja 1992 roku$^{5}$. Konwencja ta stanowi najważniejszy międzynarodowy akt prawny w zakresie ochrony klimatu. W art. 2 Konwencji Klimatycznej jasno sprecyzowano jej podstawowy cel, którym jest „doprowadzenie, zgodnie $\mathrm{z}$ właściwymi postanowieniami konwencji (zobowiązania

4 L. Karski, System Zielonych Inwestycji (GIS) - nowy mechanizm ochrony klimatu, PUG z 2010 r., Nr 4, s. 19.

5 Dz. U. z 1996 r. Nr 53, poz. 238. 
zawarte w art. 4 Konwencji Klimatycznej - przyp. K.K.), do ustabilizowania koncentracji gazów cieplarnianych w atmosferze na poziomie, który zapobiegałby niebezpiecznej antropogenicznej ingerencji w system klimatyczny. Dla uniknięcia zagrożenia produkcji żywności i dla umożliwienia zrównoważonego rozwoju ekonomicznego poziom taki powinien być osiągnięty w okresie wystarczającym do naturalnej adaptacji ekosystemów do zmian klimatu". Ponadto państwa - strony Konwencji zobowiązały się na mocy art. 4 ust. 2 pkt b) do osiągnięcia poziomu emisji gazów cieplarnianych z 1990 roku, przed upływem ówczesnej dekady.

Jednakże Konwencja Klimatyczna miała jedynie deklaratywną formę, a do jej skonkretyzowania doszło podczas III Sesji Konferencji Stron Ramowej Konwencji Narodów Zjednoczonych w sprawie zmian klimatu, która zaowocowała podpisaniem 11 grudnia 1997 roku Protokołu do Ramowej Konwencji Narodów Zjednoczonych w sprawie zmian klimatu, zwanym Protokołem z Kioto. Na jego mocy ustalono normy dotyczące obniżenia emisji gazów cieplarnianych dla poszczególnych krajów oraz mechanizmy służące realizacji tego programu: Handel Emisjami (Emissions Trading), Mechanizm Czystego Rozwoju (Clean Development Mechanism) oraz Mechanizm Wspólnych Wdrożeń (Joint Implementation $)^{6}$. Do ratyfikacji przez Polskę Ramowej Konwencji Narodów Zjednoczonych w sprawie zmian klimatu doszło 26 października 1994 roku, natomiast Protokół z Kioto ratyfikowano 13 grudnia 2002 roku.

Jednostki przyznanej emisji (AAUs) są to jednostki emisji gazów cieplarnianych, jakie kraj z załącznika B Protokołu z Kioto ma prawo wyemitować podczas pierwszego okresu rozliczeniowego, tzn. w latach 2008-2012. Zgodnie z art. 17 Protokołu z Kioto takie państwo może uczestniczyć w handlu emisjami, który będzie miał charakter uzupełniający w stosunku do działań krajowych mających na celu wypełnienie ilościowych zobowiązań do ograniczenia i redukcji emisji. Nadwyżka jednostek przyznanej emisji nazywana jest hot air z uwagi na to, że reduk-

6 J. Szymczyk, Problemy zwiq̨zane z wprowadzaniem do Praktyki Protokołu z Kioto w Polsce oraz w krajach Unii Europejskiej, Rynek Energii z 2006 r., Nr 1, s. 2. 
cja emisji gazów cieplarnianych osiągnięta została głównie dzięki upadkowi energochłonnych przedsiębiorstw, nie zaś poprzez planowane działania. Polska, a także inne państwa Europy Środkowo - Wschodniej: Rosja, Litwa, Łotwa, Estonia, Ukraina, Czechy, Słowacja, Rumunia, Bułgaria posiadają nadwyżkę jednostek przyznanej emisji ${ }^{7}$.

Na mocy wspomnianego art. 17 Protokołu z Kioto strony wymienione $\mathrm{w}$ załączniku B do Protokołu mogą uczestniczyć w handlu emisjami dla celów wywiązania się ze zobowiązań wynikających z art. 3 Protokołu. Jednostki przyznanej emisji mogą zostać sprzedane krajom z Załącznika I do Protokołu, które nie są w stanie sprostać celom redukcyjnym. Do krajów tych zalicza się Japonię oraz niektóre kraje należące do Unii Europejskiej przed akcesją nowych członków w 2004 r. (UE 15) takie jak: Hiszpania, Portugalia, Holandia, Belgia, Austria, Irlandia. Jednakże dla potencjalnych nabywców ważne jest, aby dochody uzyskane ze sprzedaży jednostek przyznanej emisji przeznaczone były na określone cele redukcyjne. Tym samym doprowadziło to do powstania systemu zielonych inwestycji.

Co ciekawe, system zielonych inwestycji nie został wyodrębniony w drodze zmiany Protokołu z Kioto a poprzez praktykę, co doprowadziło do powstania zwyczaju, a być może nawet prawa zwyczajowego, w prawie międzynarodowym publicznym ${ }^{8}$. System zielonych inwestycji stanowi pochodną mechanizmu

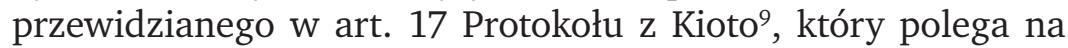
wykorzystaniu środków pochodzących ze sprzedaży jednostek przyznanej emisji na realizację działań związanych z ograniczaniem negatywnych zmian klimatu i ograniczaniem emisji gazów cieplarnianych. Tym samym środki finansowe pochodzące z systemu zielonych inwestycji mogą być przeznaczone zarówno na

7 A. Tuerk, D. Frieden, M. Sharmina, H. Schreiber, D. Ürge-Vorsatz, Working Paper, Green Investment Schemes: First experiences and lessons, April 2010, s. 1.

8 L. Karski, op. cit., s. 16.

9 A. Tuerk, D. Frieden, M. Sharmina, H. Schreiber, D. Ürge-Vorsatz, op. cit, s. 3; Uzasadnienie do ustawy z dnia 17 lipca 2009 roku o systemie zarzadzania emisjami gazów cieplarnianych i innych substancji, s. 16. 
projekty bezpośrednio redukujące emisje gazów cieplarnianych (projekty, których redukcje emisji są mierzalne) oraz projekty pośrednio wzmacniające zdolność kraju do wypełniania wszystkich zobowiązań związanych z przeciwdziałaniem negatywnym zmianom klimatu, budujące szeroko pojętą politykę i strategię zmian klimatu (projekty, w których redukcje są niemierzalne) ${ }^{10}$.

Projekty, w których redukcje emisji są mierzalne, odbywają się w ramach tzw. twardego zazieleniania - hard greening. Jest to proces, w którym działania finansowane ze sprzedaży jednostek przyznanej emisji będą przyczyniać się do wygenerowania jednostki redukcji emisji, które można zmierzyć w stosunku do linii bazowej, określonej jako emisja w przypadku braku projektu. Natomiast projekty, w których redukcje są niemierzalne, odbywają się w ramach tzw. miękkiego zazieleniania - soft greening. Jest to działalność przyczyniająca się do efektywnego wdrożenia projektów poprzez efektywne zarządzanie, likwidację subsydiowania energetyki, budowę uczestnictwa w programie ${ }^{11}$. Obecnie wśród krajów, które posiadają nadwyżkę jednostek przyznanej emisji, dominuje twarde zazielenienie ${ }^{12}$. Dla większości krajów sprzedających jednostki przyznanej emisji, obszarami priorytetowymi, w których mają być realizowane programy i projekty w ramach systemu zielonych inwestycji, są efektywność wykorzystania energii w budynkach oraz zamiana tradycyjnych paliw na paliwa oparte o odnawialne źródła energii, a co więcej, technologie czystego węgla, budowanie zdolności instytucjonalnej, produkcja biogazu dla transportu oraz gospodarka leśna ${ }^{13}$.

Koncepcja systemu zielonych inwestycji zrodziła się w 2000 roku w Rosji podczas rozmów na temat ratyfikacji Protokołu z Kioto ${ }^{14}$. Jednakże pierwszą próbę jego zdefiniowania podjęto w raporcie Banku Światowego na zlecenie rządu Buł-

10 Działania na rzecz redukcji emisji i adaptacji do zmian klimatu, Zmiany klimatu - Biuletyn Informacyjny IOŚ z 2009 r., Nr 18, s. 8.

11 Y. Umeda, GIS nadzieja zielonych inwestycji w Polsce, Wokół Energetyki, październik 2005, s. 28.

12 A. Tuerk, D. Frieden, M. Sharmina, H. Schreiber, D. Ürge-Vorsatz, op. cit., s. 27.

13 Ibidem.

14 N. Gorina, Cooling down Hot Air, Global Carbon, May 2006, s. 47. 
garii w roku 2005¹5. Mimo, iż Bułgaria była prekursorem w pracach nad systemem zielonych inwestycji, od 2005 roku poczyniła niewielkie postępy w kierunku wprowadzenia wewnętrznego uregulowania dotyczącego tego mechanizmu. Dopiero 9 czerwca 2010 roku Parlament Bułgarii uchwalił zmiany do ustawy o ochronie środowiska wprowadzając tym samym regulacje dotyczące bułgarskiego krajowego systemu zielonych inwesty$\mathrm{cji}^{16}$. Niemal w tym samym czasie niezbędne uregulowania zostały wprowadzone w Rumunii. Decyzją Rządu Rumunii nr 432 z dnia 28 kwietnia 2010 roku stworzono prawne i instytucjonalne podstawy do wprowadzenia i rozwoju systemu zielonych inwestycji ${ }^{17}$.

Jak już wspomniano, system zielonych inwestycji, jako instrument, nie został formalnie usankcjonowany $\mathrm{w}$ prawie międzynarodowym publicznym. Z uwagi na to, iż brak jest międzynarodowej regulacji traktatowej, która jasno określałaby ramy systemu zielonych inwestycji, krajowe regulacje prawne państw wprowadzających ten mechanizm mogą się od siebie różnićn ${ }^{18}$. Jednakże programy, na jakie przeznaczone zostaną dochody ze sprzedaży jednostek przyznanej emisji, muszą zostać zaakceptowane przez rządy obu krajów: kupującego i sprzedającego. W niemal wszystkich krajach nabywanie jednostek przyznanej emisji zarezerwowano dla rządów. Wyjątek stanowi Japonia, gdzie poza rządem przedsiębiorstwa mogą same nabywać jednostki przyznanej emisji po to, by sprostać swoim wewnętrznym celom $^{19}$.

Jak się okazuje, posiadanie przejrzystego i wiarygodnego systemu zielonych inwestycji odgrywa istotną rolę w prowadzeniu transakcji międzynarodowych. Z uwagi na to, że zasoby jednostek przyznanej emisji przewyższają popyt, wpływ inicjatyw

15 Opinions for Designing a Green Investment Scheme for Bulgaria.

16 Http://www.global-carbon.com/en/290/news.html z dnia 24 marca 2011 roku.

17 Monitorul Oficial nr. 303 din 10 mai 2010 (rumuński odpowiednik polskiego Dziennika Ustaw).

18 L. Karski, op. cit., s. 19.

19 A. Tuerk, D. Frieden, M. Sharmina, H. Schreiber, D. Ürge-Vorsatz, op. cit., s. 2 . 
opartych na systemie zielonych inwestycji na rynku będzie zależał od wymogów kupującego, dotyczących głównie wiarygodności systemu zielonych inwestycji. Większość publicznych nabywców ostrożnie dobiera partnerów, kupując jednostki przyznanej emisji od krajów, które gwarantują przejrzysty sposób „zazielenienia" jednostek. Jednakże wielu znaczących nabywców jednostek przyznanej emisji, włącznie z japońskimi przedsiębiorstwami, zawarło umowy sprzedaży jednostek z krajami, których system zielonych inwestycji nie jest dostatecznie wiarygodny ${ }^{20}$.

Warto zauważyć, że istnieje pewne podobieństwo systemu zielonych inwestycji do mechanizmu wspólnych wdrożeń, który został wprowadzony art. 6 Protokołu z Kioto. Mechanizm wspólnych wdrożeń polega na wspólnej realizacji projektów pomiędzy krajami z Załącznika I Ramowej Konwencji (państwem - inwestorem a państwem goszczącym - gospodarzem projektu), a jego celem jest obniżenie kosztów redukcji emisji w poszczególnych krajach wymienionych w Załączniku $\mathrm{I}^{21}$. Różnicowanie kosztów redukcji emisji gazów w państwach z Załącznika I stanowi zasadę, na której opiera się cały mechanizm. Zobowiązania redukcyjne państwa - inwestora mogą zostać wypełnione poprzez zaliczenie redukcji uzyskanej w wyniku inwestycji w innym kraju - państwie goszczącym - będącym gospodarzem projektu. W praktyce, koszty redukcji emisji państwa - inwestora ulegają zmniejszeniu w porównaniu do kosztów, jakie musiałby ponieść realizując inwestycje krajowe, a tym samym zwiększa swój limit emisji. Z drugiej strony, w państwie, będącym gospodarzem projektu, wprowadzone zostają nowoczesne i przyjazne dla środowiska technologie, a emisja gazów cieplarnianych zostaje obniżona. Skutkiem realizacji projektów opartych na mechanizmie wspólnych wdrożeń w wyniku zamiany jednostek przyznanej emisji powstają jednostki redukcji emisji (ERU22), które stanowią środek służący krajom Załącznika I w wypełnianiu zobowią-

20 Ibidem.

21 M. Górski, Ochrona powietrza, [w:] M. Górski (red.) Prawo ochrony środowiska, Warszawa 2009, s. 247.

22 Ang. Emission Reduction Unit. 
zań wynikających z Protokołu z Kioto. Jednostki redukcji emisji mogą być generowane w latach 2008-2012 ${ }^{23}$.

Mechanizm wspólnych wdrożeń jest zawsze związany z określonym projektem. Zgodnie z art. 6 ust. 1 Protokołu z Kioto „dla wypełnienia zobowiązań wynikających z art. 3 każda Strona wymieniona w załączniku I może przekazać innej takiej Stronie lub od niej nabyć jednostki redukcji emisji powstałe w wyniku realizacji projektów mających na celu redukcję antropogenicznych emisji gazów cieplarnianych ze źródeł lub zwiększenie ich antropogenicznego pochłaniania we wszystkich sektorach gospodarki, pod warunkiem, że:

a) każdy projekt został zaakceptowany przez zaangażowane Strony;

b) każdy projekt zapewnia dodatkową redukcję emisji ze źródeł lub zwiększa pochłanianie gazów cieplarnianych w porównaniu do sytuacji, jaka miałaby miejsce, gdyby projekt nie został zrealizowany;

c) Strona nie nabywa jednostek redukcji emisji, jeśli nie wypełnia swoich zobowiązań wynikających z art. 5 i 7 oraz

d) nabycie jednostek redukcji emisji uzupełnia działania krajowe podejmowane w celu wypełnienia zobowiązań wynikających z art. 3"24.

System zielonych inwestycji jest mniej restrykcyjny niż mechanizm wspólnych wdrożeń. Kapitał uzyskany w wyniku transakcji określonych w art. 17 Protokołu z Kioto może być przeznaczony na dowolne inwestycje proekologiczne ${ }^{25}$. Kraje, będące gospodarzami projektu czyli te, w których inwestycje są realizowane, wprowadzają system zielonych inwestycji w tych obszarach, gdzie mechanizm wspólnych wdrożeń nie zdaje egzaminu, a które mają dla nich duże znaczenie strategiczne. W przeciwieństwie do mechanizmu wspólnych wdrożeń system zielonych inwestycji zapewnia finansowanie $\mathrm{z}$ góry i nie jest ograniczany

23 A. Gałan, P. Dombrowicki, Z. Pisarski, I. Zborowska, Projekty wspólnych wdrożeń - możliwości realizacji w Polsce. Przewodnik dla inwestorów, Warszawa 2010, s. 21.

24 Dz. U. z 2005 r. Nr 203, poz. 1684.

25 Y. Umeda, op. cit., s. 28. 
okresami kredytowania. System zielonych inwestycji zakłada wdrożenie podobnych projektów do tych, które mogą być wprowadzone przy wykorzystaniu mechanizmu wspólnych wdrożeń, upraszczając jednocześnie warunki ich wprowadzenia ${ }^{26}$. Do zalet systemu zielonych inwestycji należy zaliczyć możliwość realizacji kompleksowych projektów programowych. W Polsce projekty te realizowane są np. na poziomie gmin, miast, województw, całego kraju, czy też sektorowo.

Dzięki systemowi zielonych inwestycji państwa z niedoborem uprawnień mogą wywiązać się z określonego Protokołem z Kioto celu redukcyjnego poprzez zakup jednostek przyznanej emisji, a tym samym zapewnią, że przekazane w związku z tym środki zostaną przeznaczone na cele środowiskowe, przede wszystkim związane z redukcją emisji gazów cieplarnianych. Dzięki temu państwo zbywające może uzyskać dodatkowe, w stosunku do już osiągniętej redukcji, obniżenie emisji gazów cieplarnianych, powiększając tym samym posiadaną nadwyżkę jednostek w ramach Protokołu z Kioto ${ }^{27}$. Omawiany mechanizm skierowany jest do państw posiadających znaczną nadwyżkę jednostek przyznanej emisji a z uwagi na to, że głównie są to państwa, które przeszły lub też obecnie przechodzą transformację społeczno - gospodarczą, system zielonych inwestycji ma służyć nie tylko ochronie środowiska ale również jego harmonizacji z rozwojem społecznym i gospodarczym ${ }^{28}$.

Do ustawodawstwa polskiego system zielonych inwestycji został wprowadzony na mocy art. 22 ustawy z 2009 r. o systemie zarządzania emisjami gazów cieplarnianych i innych substancji. Podyktowane to było tym, iż w okresie transformacji ustrojowej oraz gospodarczej Polska znacznie zredukowała emisję gazów cieplarnianych w porównaniu z 1988 rokiem - przyjętym dla niej rokiem bazowym - i obecnie posiada trzecią co do wielkości, po Rosji i Ukrainie, nadwyżkę jednostek przyznanej emisji. Skutek taki wywarły restrukturyzacja polskiej gospodarki przepro-

26 A. Tuerk, D. Frieden, M. Sharmina, H. Schreiber, D. Ürge-Vorsatz, op. cit, s. 40.

27 Działania na rzecz redukcji emisji..., s. 8.

28 L. Karski, op. cit., s. 19. 
wadzona po 1990 roku, działania na rzecz środowiska, a także upadek niektórych energochłonnych przedsiębiorstw w okresie transformacji ${ }^{29}$.

Wprowadzenie przez Polskę środków prawnych w postaci uregulowań zawartych w przedmiotowej ustawie z 2009 r., stanowiących zachętę dla potencjalnych nabywców do przyjęcia oferty sprzedaży jednostek przyznanej emisji, stało się więc nieuchronne, gdyż warunkiem dokonania sprzedaży jednostek jest zagwarantowanie przez sprzedającego wykorzystania całości przychodów ze sprzedaży na dofinansowanie przedsięwzięć związanych z szeroko pojętą ochroną klimatu i środowiska. Natomiast cena, którą można uzyskać ze sprzedaży jednostek, uzależniona jest od pewności i przejrzystości zaproponowanych procedur, a co więcej od podaży jednostek na międzynarodowym rynku ${ }^{30}$.

Wprowadzając na podstawie art. 22 ustawy z 2009 r. krajowy system zielonych inwestycji Polska dostosowała swoje prawo do przedstawionych wymogów. Warto zauważyć, że do dnia wejścia w życie przedmiotowych uregulowań obowiązywała jedynie ustawa z dnia 22 grudnia 2004 r. o handlu uprawnieniami do emisji do powietrza gazów cieplarnianych i innych substan$\mathrm{cji}^{31}$, która jednak nie regulowała transakcji jednostkami przyznanej emisji.

Wykorzystanie środków pochodzących ze sprzedaży jednostek przyznanej emisji przebiega z zachowaniem uzgodnionych z państwem nabywcą i sprecyzowanych w umowie sprzedaży warunków, m.in. w zakresie terminów wykorzystania tych środków, przeznaczenia na określone rodzajowo przedsięwzięcia, przekazywania informacji dotyczących uzyskanych efektów ekologicznych. Krajowy system zielonych inwestycji gwarantuje zatem z jednej strony, że państwo z niedoborem uprawnień bę-

29 Ministerstwo Środowiska, Zarabiamy na emisjach, Środowisko z 2009 r., Nr 22, s. 16.

30 Uzasadnienie do ustawy..., s. 17.

31 Dz. U. 2004 r. Nr 281, poz. 2784 ze zm.; akt ten został uchylony ustawą z dnia 28 kwietnia 2011 r. o systemie handlu uprawnieniami do emisji gazów cieplarnianych, Dz. U. z 2011 r. Nr 122, poz. 695. 
dzie mogło poprzez zakup jednostek zwiększyć emisję gazów cieplarnianych i jednocześnie, że przekazane w związku z tym środki, zostaną przeznaczone przez sprzedającego na określone cele związane z redukcją emisji. Takie wykorzystanie środków ze sprzedaży jednostek przyznanej emisji jest ściśle określone w umowie sprzedaży i warunkuje jej ważnośćc ${ }^{32}$.

Zgodnie z art. 22 ust. 1 ustawy „tworzy się Krajowy system zielonych inwestycji, w ramach którego środki uzyskane ze zbycia w latach 2009-2012 jednostek przyznanej emisji są przeznaczane na dofinansowanie realizacji na terytorium Rzeczypospolitej Polskiej:

1) programów lub projektów związanych z ochroną środowiska, w szczególności z ograniczeniem lub unikaniem krajowej emisji gazów cieplarnianych, pochłanianiem lub sekwestracją dwutlenku węgla $\left(\mathrm{CO}_{2}\right)$;

2) działań adaptacyjnych do zmian klimatu;

3) innych działań związanych z ochroną powietrza".

Obszary, w których mają być realizowane programy i projekty w ramach systemu zielonych inwestycji zostały enumeratywnie wymienione w art. 22 ust. 2 ustawy o systemie zarządzania emisjami gazów cieplarnianych i innych substancji. Zgodnie z ust. 2 wspomnianego artykułu: „Programy lub projekty, o których mowa w ust. 1 (związane z ochroną środowiska, w szczególności z ograniczeniem lub unikaniem krajowej emisji gazów cieplarnianych, pochłanianiem lub sekwestracją dwutlenku węgla $\left(\mathrm{CO}_{2}\right.$ - przyp. K.K.), są realizowane w obszarach:

1) poprawy efektywności energetycznej w różnych sektorach gospodarki;

2) poprawy efektywności wykorzystania węgla, w tym związanej z czystymi technologiami węglowymi;

3) zamiany stosowanego paliwa na paliwo niskoemisyjne;

4) unikania lub redukcji emisji gazów cieplarnianych w sektorze transportu;

5) wykorzystania odnawialnych źródeł energii;

32 Uzasadnienie do ustawy..., s. 17. 
6) unikania lub redukcji emisji metanu przez jego odzyskiwanie i wykorzystywanie w przemyśle wydobywczym, gospodarce odpadami i ściekami oraz w gospodarce rolnej, a także przez wykorzystywanie go do produkcji energii;

7) działań związanych z sekwestracją gazów cieplarnianych;

8) innych działań zmierzających do ograniczania lub unikania krajowej emisji gazów cieplarnianych lub pochłaniania dwutlenku węgla $\left(\mathrm{CO}_{2}\right)$ oraz adaptacji do zmian klimatu;

9) prowadzenia prac badawczo-rozwojowych w zakresie wykorzystania odnawialnych źródeł energii oraz zaawansowanych i innowacyjnych technologii przyjaznych środowisku;

10) działalności edukacyjnej, w tym prowadzenia szkoleń wspomagających wypełnianie krajowych zobowiązań wynikających z Protokołu z Kioto".

Wyżej wymieniona regulacja ma zagwarantować równy dostęp do środków wszystkich sektorów: przemysłu, leśnictwa, rolnictwa, transportu, natomiast preferowane będą te obszary, w których działania będą najefektywniejsze pod względem ekologiczno-ekonomicznym ${ }^{33}$.

Na mocy art. 23 ustawy z 2009 r. przewidziano utworzenie rachunku klimatycznego, który stanowi wyodrębniony rachunek bankowy Narodowego Funduszu Ochrony Środowiska i Gospodarki Wodnej, na którym gromadzone są wpływy pochodzące ze sprzedaży jednostek przyznanej emisji. Takie rozwiązanie przyjęto również w innych krajach wykorzystujących system zielonych inwestycji, takich jak: Czechy, Węgry, Estonia czy Bułgaria, zaś na Łotwie dochody ze sprzedaży jednostek przyznanej emisji gromadzone są na rachunku budżetowym ${ }^{34}$.

Rozwiązanie przyjęte $\mathrm{w}$ polskiej ustawie wprowadzającej regulacje dotyczące krajowego systemu zielonych inwestycji jest zbieżne z wymaganiami państw kupujących jednostki przyznanej

${ }_{33}$ Ministerstwo Środowiska, Ustawa o systemie zarzqdzania emisjami gazów cieplarnianych $i$ innych substancji, NEWSLETTER z 2009 r., Nr 7, s. 3.

${ }^{34}$ A. Tuerk, D. Frieden, M. Sharmina, H. Schreiber, D. Ürge-Vorsatz, op. cit, s. $5,7,10,13$ i 17. 
emisji. Dla tej grupy państw istotne jest, aby wpływy pochodzące ze sprzedaży wspomnianych jednostek przeznaczane były na konkretne projekty związane z ochroną środowiska. Wiadomo, że państwa dysponujące nadwyżką wspomnianych jednostek, w tym Polska, często mają trudności z utrzymaniem dyscypliny finansowej a także borykają się z problemami budżetowymi. Dlatego też istotne jest, aby wpływy pochodzące ze sprzedaży jednostek przyznanej emisji zasilały specjalny rachunek bankowy poszczególnych państw a środki zgromadzone na tym rachunku nie były przeznaczane na wydatki nie związane z systemem zielonych inwestycji ${ }^{35}$.

Dla poprawnego funkcjonowania systemu zielonych inwestycji istotne jest również, aby był on w sposób odpowiedni zarządzany. Na mocy polskiej ustawy z 2009 r. instytucją zarządzającą krajowym systemem zielonych inwestycji jest powołany w art. 25 krajowy operator systemu zielonych inwestycji, którego zadania wykonuje Narodowy Fundusz Ochrony Środowiska i Gospodarki Wodnej. Do kompetencji krajowego operatora należy przygotowanie i przedłożenie ministrowi właściwemu do spraw środowiska raportów wynikających z postanowień umów o sprzedaży jednostek przyznanej emisji. Ponadto organizuje on nabór wniosków o dofinansowanie ze środków zgromadzonych na rachunku klimatycznym i zajmuje się ich weryfikacją, jak również sporządza listy programów i projektów, które zostały wstępnie zakwalifikowane do dofinansowania ze środków zgromadzonych na rachunku klimatycznym, a następnie prowadzeniem wykazu programów i projektów dofinansowanych ze środków zgromadzonych na rachunku klimatycznym, nadzorowaniem ich wdrażania i realizacji a także ocenia uzyskane przez nie efekty ekologiczne. Narodowy Fundusz Ochrony Środowiska i Gospodarki Wodnej jest również zobowiązany do organizowania pomocy technicznej dla potencjalnych beneficjentów, natomiast beneficjenci zobowiązani są do sporządzania raportów i sprawozdań. Informacje w nich zawarte wprowadzane są do krajowej bazy, której prowadzenie leży również w gestii krajowe- 
go operatora. Ponadto krajowy operator sprawuje kontrolę nad wykorzystaniem przez beneficjentów przyznanych im środków, jak również prowadzi działalność promocyjną i informacyjną o krajowym systemie zielonych inwestycji.

Nabór wniosków o udzielenie dofinansowania ze środków zgromadzonych na rachunku klimatycznym dla programów lub projektów w ramach krajowego systemu zielonych inwestycji odbywa się w trybie konkursowym, którego organizacją, oceną, nadzorowaniem wdrażania i realizacji oraz kontrolą końcowych efektów ekologicznych wdrożonych projektów zajmuje się NFOŚiGW. W art. 28 ust. 1 ustawy ustawodawca przewidział, iż „dofinansowania ze środków zgromadzonych na rachunku klimatycznym realizacji programów i projektów, o których mowa w art. 22, dokonuje się $\mathrm{w}$ formie dotacji, $\mathrm{w}$ tym dotacji przeznaczanych na dopłaty do oprocentowania kredytów bankowych oraz dotacji przeznaczanych na częściową spłatę kapitału kredytów bankowych". W ustępie 2 wspomnianego artykułu wprowadzono regulację, która określa, że „w zakresie, w którym dofinansowanie programów i projektów stanowi pomoc spełniającą przesłanki określone w art. 87 ust. 1 Traktatu ustanawiającego Wspólnotę Europejską ${ }^{36}$ albo pomoc de minimis, do tego dofinansowania mają zastosowanie szczegółowe warunki udzielania pomocy". Zgodnie z ust. 3 art. 28 ustawy z 2009 r., wspomniane szczegółowe warunki udzielania pomocy zostaną określone w drodze rozporządzenia.

Należy zauważyć, że ustawa o systemie zarządzania emisjami gazów cieplarnianych i innych substancji pochodzi z dnia 17 lipca 2009 roku, a w dniu 1 grudnia tego roku wszedł w życie Traktat z Lizbony ${ }^{37}$ zmieniający Traktat o Unii Europejskiej ${ }^{38}$ i Traktat ustanawiający Wspólnotę Europejską, który został podpisany 13 grudnia 2007 roku. Zgodnie z art. 2 ust. 1 nagłówek Traktatu ustanawiającego Wspólnotę Europejską zostaje zmieniony na Traktat o funkcjonowaniu Unii Europejskiej. Obecnie art. 107 Traktatu o funkcjonowaniu Unii Europejskiej zawiera

36 Dz. U. z 2004 r. Nr 90, poz. 864/2 ze zm.

37 Dz. U. z 2009 r. Nr 203, poz. 1569.

38 Dz. U. z 2004 r. Nr 90, poz. 864/30 ze zm. 
regulację wcześniej zawartą we wspomnianym art. 87 Traktatu ustanawiającego Wspólnotę Europejską.

System zielonych inwestycji stanowi przykład tego, w jaki sposób w prawie międzynarodowym publicznym dochodzi do powstania zwyczaju, a może i prawa zwyczajowego. Mimo, iż system ten nie ma swojego unormowania w prawie traktatowym, na podstawie powyższych rozważań można zauważyć, że cieszy się dużym zainteresowaniem i z czasem przenika do krajowych porządków prawnych. System zielonych inwestycji stanowi odpowiedź na kontrowersyjną kwestię handlu emisjami. Pomimo, że międzynarodowe regulacje zezwalają na obniżenie emisji gazów cieplarnianych poprzez zakup jednostek od państw, które dysponują ich nadwyżką, wykształcił się mechanizm, za pośrednictwem którego wpływy ze sprzedaży jednostek nie będą wykorzystywane na bieżące wydatki z budżetów poszczególnych państw a na jasno i konkretnie sprecyzowane cele ekologiczne. Co ciekawe, większą szansę na sprzedaż swoich jednostek mają te państwa, które dysponują bardziej wiarygodnym i przejrzystym systemem zielonych inwestycji.

Polska należy do państw posiadających nadwyżkę jednostek przyznanej emisji. Na mocy wprowadzonej do jej ustawodawstwa ustawy o systemie zarządzania emisjami gazów cieplarnianych i innych substancji uregulowany został system zielonych inwestycji oparty na jasnej regulacji prawnej, która jednoznacznie określa, jakie programy i projekty mogą być finansowane ze środków uzyskanych ze sprzedaży jednostek przyznanej emisji. Co więcej, w ustawie o systemie zarządzania emisjami gazów cieplarnianych i innych substancji wprowadzono organ zarządzający, dzięki któremu system zielonych inwestycji może funkcjonować w praktyce.

Jak dotąd doszło do podpisania przez Polskę czterech umów sprzedaży jednostek przyznanej emisji: z Europejskim Bankiem Odbudowy i Rozwoju działającym na rzecz Rządu Hiszpanii i Rządu Irlandii oraz 2 prywatnymi firmami z Japonii ${ }^{39}$.

39 http://www.nfosigw.gov.pl/o-nfosigw/aktualnosci/art.196,zarabiamyna-klimacie-system-zielonych-inwestycji.html z dnia 24 marca 2011 r. 


\section{BIBLIOGRAFIA}

Działania na rzecz redukcji emisji i adaptacji do zmian klimatu, Zmiany klimatu - Biuletyn Informacyjny IOŚ z 2009 r., Nr 18.

Gałan A., Dombrowicki P., Pisarski Z., Zborowska I., Projekty wspólnych wdrożeń - możliwości realizacji $w$ Polsce. Przewodnik dla inwestorów, Warszawa 2010.

Gorina N., Cooling down Hot Air, Global Carbon, May 2006.

Górski M. (red.) Prawo ochrony środowiska, Warszawa 2009.

Karski L., System Zielonych Inwestycji (GIS) - nowy mechanizm ochrony klimatu, PUG z 2010 r.

Ministerstwo Środowiska, Ustawa o systemie zarzqdzania emisjami gazów cieplarnianych $i$ innych substancji, NEWSLETTER z 2009 r.

Ministerstwo Środowiska, Zarabiamy na emisjach, Środowisko z 2009 r., Nr 22.

Opinions for Designing a Green Investment Scheme for Bulgaria.

Szymczyk J., Problemy zwiqzane z wprowadzaniem do Praktyki Protokotu z Kioto $w$ Polsce oraz $w$ krajach Unii Europejskiej, Rynek Energii z $2006 \mathrm{r}$.

Tuerk A., Frieden D., Sharmina M., Schreiber H., Ürge-Vorsatz D., Working Paper, Green Investment Schemes: First experiences and lessons, April 2010.

Umeda Y., GIS nadziejq zielonych inwestycji w Polsce, Wokół Energetyki, październik 2005.

Uzasadnienie do ustawy z dnia 17 lipca 2009 roku o systemie zarzqdzania emisjami gazów cieplarnianych i innych substancji.

http://www.global-carbon.com/en/290/news.html z dnia 24 marca 2011 roku.

http://www.nfosigw.gov.pl/o-nfosigw/aktualnosci/art,196, zarabiamy-na-klimacie-system-zielonych-inwestycji.html z dnia 24 marca 2011 r.

Kontakt e-mail:

kasiakierzkowska@gmail.com 